Article

\title{
Low R/FR Ratio Affects Pakchoi's Growth and Nitrate Content under Excess Nitrate Stress
}

\author{
Libang Chen ${ }^{\dagger}$, Jia Huang ${ }^{\dagger}$, Qinglin Liu, Zelin Li, Xu Chen, Jiaxi Han, Yirong Gan, Yuexuan He, Chenxiang Jiang, \\ Yunxin Tang and Xiaoting Zhou * (D)
}

check for updates

Citation: Chen, L.; Huang, J.; Liu, Q.; Li, Z.; Chen, X.; Han, J.; Gan, Y.; He, Y.; Jiang, C.; Tang, Y.; et al. Low R/FR Ratio Affects Pakchoi's Growth and Nitrate Content under Excess Nitrate Stress. Horticulturae 2022, 8, 186. https://doi.org/10.3390/ horticulturae 8030186

Academic Editor: Haijun Gong

Received: 30 December 2021

Accepted: 17 February 2022

Published: 22 February 2022

Publisher's Note: MDPI stays neutral with regard to jurisdictional claims in published maps and institutional affiliations.

Copyright: (C) 2022 by the authors. Licensee MDPI, Basel, Switzerland. This article is an open access article distributed under the terms and conditions of the Creative Commons Attribution (CC BY) license (https:// creativecommons.org/licenses/by/ $4.0 /)$.
College of Horticulture, Sichuan Agricultural University, Chengdu 611130, China; clibang2022@163.com (L.C.); huang_jia@163.com (J.H.); lq11975215079@163.com (Q.L.); nc_2008@126.com (Z.L.); chenxu_irly@163.com (X.C.); h_tevanm@163.com (J.H.); gyirong_2001@163.com (Y.G.); heyuexuan2002@163.com (Y.H.); jiangchenxiang0525@163.com (C.J.); tang1922045418@163.com (Y.T.)

* Correspondence: zhouxiaoting6412@hotmail.com

+ These authors contributed equally to this work.

\begin{abstract}
Nitrate accumulation is one of the main factors of secondary soil salinization in protected horticulture in China. Previous studies have shown that a low red(R)/far-red (FR) ratio can improve the salt tolerance of plants under $\mathrm{NaCl}$ stress. However, the effect of a low $\mathrm{R} / \mathrm{FR}$ ratio on plant growth under nitrate stress is not clear. In order to explore the effect of a low R/FR ratio on the adaptability of pakchoi under high nitrogen stress, the growth index, soluble protein content, soluble sugar content, nitrate content, nitrate reductase activity and Nia2 gene expression of pakchoi's leaves were measured. The results showed that a high level of nitrogen (the addition of $80 \mathrm{mmol} \cdot \mathrm{L}^{-1} \mathrm{NO}_{3}{ }^{-}(\mathrm{N} 80)$ and $160 \mathrm{mmol} \cdot \mathrm{L}^{-1} \mathrm{NO}_{3}{ }^{-}$(N160)) inhibited the growth of pakchoi and promoted the accumulation of osmoregulation substances and nitrate content, respectively. The reduction of the R/FR ratio under high nitrogen stress (L80) increased the fresh weight of the plants under it by $19.0 \%$, reduced the nitrate content in the leaves by $22.7 \%$, increased the NR activity by $29.9 \%$, and made the Nia 2 gene expression more significant, compared with N80. There was a similar mitigation effect of a low R/FR ratio under $160 \mathrm{mmol} \cdot \mathrm{L}^{-1}$ excessive $\mathrm{NO}_{3}{ }^{-}$stress. Therefore, the reduction of the $\mathrm{R} / \mathrm{FR}$ ratio can effectively control the nitrate content and improve the adaptability of pakchoi under high nitrogen stress. Thus, there is a practical application prospect for a low R/FR ratio for the production of pakchoi under a high level of nitrogen.
\end{abstract}

Keywords: pakchoi; nitrate content; nitrate stress

\section{Introduction}

Protected vegetable cultivation in a greenhouse is considered to be a good method for a stable yield and high quality of vegetables. By using insect prevention nets, environmental control and other facilities to block the harm of pests and reduce the impact of disastrous weather, it plays an important role in the stabilization of urban vegetable supply. In recent years, the problem of soil secondary salinization in greenhouses caused by continuous cropping, a high multiple cropping index and excessive fertilization has become more and more serious in China. Reports have shown that the main salt of secondary saline soil is $\mathrm{Ca}\left(\mathrm{NO}_{3}\right)_{2}$, rather than $\mathrm{NaCl}[1,2]$. Research has shown that the harm of excessive $\mathrm{NO}_{3}{ }^{-}$to plants is mainly manifested in the inhibition of seed germination [3], the disorder of the antioxidant enzyme system [4], the inhibition of growth, and the accumulation of osmotic regulatory substances.

Recently, more and more studies have shown that light environment regulation not only promotes crop growth but also plays an important role in improving plant stress resistance. In the natural environment, the green leaves of plants absorb red light, and increase the proportion of far-red light through reflection and transmission, resulting in the decrease of the ratio of $\mathrm{R} / \mathrm{FR}$ around the leaves. Plants feel the change of the ratio of 
$\mathrm{R} / \mathrm{FR}$ in the environment through phytochromes, resulting in the increase of plant height and internode elongation. Studies have shown that, under the same light intensity, a low proportion of R/FR can improve the photosynthetic capacity and dry matter accumulation of plants [5-7]. The supplementation of far-red light to reduce the ratio of $R / F R$ can improve the photochemical efficiency and carbon fixation abilities of soybean, so as to improve the growth quality of soybean [8]. In addition, studies have found that a low $\mathrm{R} / \mathrm{FR}$ ratio can alleviate low-temperature [9], drought [10] and salt stress [11], and can participate in the regulation of signal pathways related to stress resistance. A low R/FR ratio allowed the infection of growth by salt stress in tomato seedlings, while the allowance was absent in the mutant $p h y B$ [11]. It has been reported that phytochromes were involved in controlling the hormone biosynthesis in plants exposed to different R/FR ratios, as well as being involved in their salt tolerance [12,13]. However, the research on the salt tolerance of the $\mathrm{R} / \mathrm{FR}$ ratio mainly focuses on $\mathrm{NaCl}$ stress. The effect of a low $\mathrm{R} / \mathrm{FR}$ ratio under $\mathrm{NO}_{3}{ }^{-}$stress remains unclear.

Pakchoi (Brassica campestris L. ssp. chinensis), known as non-heading Chinese cabbage, is one of the most widely cultivated and popular vegetables in China because of its rich nutritional value and short growth period [14]. However, high concentrations of nitrates seriously damage human health [15]. Excessive $\mathrm{NO}_{3}{ }^{-}$not only inhibits the growth of pakchoi but also causes a high nitrate content in pakchoi leaves. Nitrate accumulation in vegetables is a complex process which is affected by light quality, nitrate nitrogen absorption, reduction and assimilation. There is a significant correlation between nitrogen fertilizer use and nitrate accumulation in vegetables [16]. In addition, nitrate reductase (NR) is the first enzyme in the process of nitrogen metabolism in higher plants [17]. It is also the rate limiting enzyme in the whole reduction process, and plays a key role in plant nitrogen metabolism [18]. Liang Liang [19] pointed out that the accumulation of nitrate is inversely proportional to the activity of nitrate reductase. Curtis et al. [20] found that increasing the expression of the nitrate reductase gene reduced the nitrate content in lettuce leaves. Under high nitrogen stress, the NR activity and nitrogen metabolism-related enzymes of cucumber were inhibited, while exogenous humic acid treatment could increase NR activity and reduce the nitrate content [4]. Therefore, it is expected to reduce the nitrate accumulation under excessive $\mathrm{NO}_{3}{ }^{-}$stress by regulating the $\mathrm{NR}$ activity of pakchoi. In this experiment, the authors will further explore the effect of a low R/FR ratio on the expression of nitrate reductase and related genes in pakchoi under nitrogen stress, so as to preliminarily reveal the mechanism of low $\mathrm{R} / \mathrm{FR}$ ratio on the regulation of nitrate content in pakchoi.

\section{Materials and Methods}

In this experiment, pakchoi (Brassica campestris L. ssp. Chinensis cv. Te Zhong Xiao Bai Cai) was used as the material. LED tubes were used as the light source. The experiment was conducted in Sichuan Agricultural University (Chengdu, China) from June 2020 to June 2021. The seeds were selected, soaked and planted in a seedling tray containing a vermiculite and perlite matrix. It was placed in a plant factory at $25 \pm 1{ }^{\circ} \mathrm{C}$ during the day and $18 \pm 1{ }^{\circ} \mathrm{C}$ at night. The photoperiod was $12 \mathrm{~h} / 12 \mathrm{~h}$ (light/darkness), the relative humidity was $70 \%$, and the light intensity was $200 \mu \mathrm{mol} \cdot \mathrm{m}^{-2} \cdot \mathrm{s}^{-1}$. The seedlings were watered by $1 / 2$ Hoagland nutrient solution every 4 days. The main elements of the nutrient solution were as follows: $\mathrm{NO}_{3}{ }^{-}\left(7.0 \mathrm{mmol} \cdot \mathrm{L}^{-1}\right), \mathrm{P}\left(0.5 \mathrm{mmol} \cdot \mathrm{L}^{-1}\right), \mathrm{K}\left(3.0 \mathrm{mmol} \cdot \mathrm{L}^{-1}\right), \mathrm{Ca}\left(2.0 \mathrm{mmol} \cdot \mathrm{L}^{-1}\right)$, $\mathrm{Mg}\left(1.0 \mathrm{mmol} \cdot \mathrm{L}^{-1}\right)$ and $\mathrm{S}\left(1.0 \mathrm{mmol} \cdot \mathrm{L}^{-1}\right)$. After 22 days of the seedling period, the seedlings were transplanted into the hydroponics box with $1 / 2$ Hoagland nutrient solution.

After 10 days of the seedling transplant stage, the plants were stressed. A total of 6 treatments were set up: (1) $\mathrm{N}$-normal nutrient supply condition, $\mathrm{R} / \mathrm{FR}=4.2$; (2) $\mathrm{L}-$ normal nutrient supply condition, $\mathrm{R} / \mathrm{FR}=0.7$; (3) $\mathrm{N} 80$ - the addition of $80 \mathrm{mmol} \cdot \mathrm{L}^{-1} \mathrm{NO}_{3}{ }^{-}$, $\mathrm{R} / \mathrm{FR}=4.2$; (4) $\mathrm{L} 80$ - the addition of $80 \mathrm{mmol} \cdot \mathrm{L}^{-1} \mathrm{NO}_{3}{ }^{-}, \mathrm{R} / \mathrm{FR}=0.7$; (5) N160-the addition of $160 \mathrm{mmol} \cdot \mathrm{L}^{-1} \mathrm{NO}_{3}{ }^{-}, \mathrm{R} / \mathrm{FR}=4.2$; (6) $\mathrm{L} 160$-added $160 \mathrm{mmol} \cdot \mathrm{L}^{-1} \mathrm{NO}_{3}{ }^{-}$, $\mathrm{R} / \mathrm{FR}=0.7 . \mathrm{Ca}\left(\mathrm{NO}_{3}\right)_{2}$ was used as the nitrogen source for the stress treatment. The concen- 
tration of $\mathrm{NO}_{3}{ }^{-}$in the normal nutrient supply was $7.0 \mathrm{mmol} \cdot \mathrm{L}^{-1}$, and the total concentration of $\mathrm{NO}_{3}{ }^{-}$under $\mathrm{N} 80$ and $\mathrm{L} 80$ was $87 \mathrm{mmol} \cdot \mathrm{L}^{-1}$, respectively; the total concentration of $\mathrm{NO}_{3}{ }^{-}$under $\mathrm{N} 160$ and $\mathrm{L} 160$ was $167 \mathrm{mmol} \cdot \mathrm{L}^{-1}$. By the addition of far-red LED light and white LED light, the R/FR ratio can be reduced. The R/FR ratio was calculated as the red light quantum flux density from 655 to $665 \mathrm{~nm}$ divided by the far-red light quantum flux density from 725 to $735 \mathrm{~nm}$. R/FR ratios of 4.2 and 0.7 were used for the control and low-R/FR ratio treatments, respectively. Regarding the lamp tubes, 8 white LED lamps were used as the control group $(\mathrm{R} / \mathrm{FR}$ ratio $=4.2)$, and 4 far-red LED lamps and 6 white LED lamps were used as the experimental group $(\mathrm{R} / \mathrm{FR}$ ratio $=0.7)$.

Five plants were taken randomly from each treatment, and the second and third fully expanded functional leaves from the top of the plant were taken, quick-frozen with liquid nitrogen, and stored at $-80^{\circ} \mathrm{C}$ for the determination of the various indexes. Samples were taken at $0 \mathrm{~h}, 3 \mathrm{~h}, 6 \mathrm{~h}, 12 \mathrm{~h}, 24 \mathrm{~h}$ and $72 \mathrm{~h}$ after high nitrate stress for the determination of the Nia 2 gene. The growth and morphological indexes were measured on the 15th day of stress, while the other indexes were measured from fresh samples on the 0th, 5th and 10th days of stress, respectively. This experiment was repeated three times, and 420 seedlings were cultivated for experiment each time.

The root length, leaf width and leaf length were measured with a ruler. The fresh weight of the plants were measured with a balance. As for the content of soluble sugar and soluble protein, they were determined by the anthrone method and coomassie brilliant blue G250, respectively [21]. The fresh leaf nitrate content was determined by the nitrosylsalicylic acid method [21], i.e., $2 \mathrm{~g}$ (powdered) leaves was boiled in $10 \mathrm{~mL}$ deionized water for $30 \mathrm{~min}$ and then filtered; the filtrate was prepared to use after being adjusted to $25 \mathrm{~mL}$ by adding deionized water. In total, $0.5 \mathrm{~g}$ leaves were ground in $4 \mathrm{~mL}$ buffer, $(25 \mathrm{mM}$ sodium phosphate buffer, $\mathrm{pH} 8.7,10 \mathrm{mM}$ L-cysteine, $1 \mathrm{mM} \mathrm{Na}_{2}$ EDTA), and the centrifuged supernatant was used to determine the nitrate reductase activity using sulfanilamide colorimetry [21].

The total RNA of the leaves was isolated using the E.Z.N.A. Plant RNA Kit (Omega Bio-tek, Doraville, GA, USA), according to the manufacturer's instructions. The FastKing one-step method (Tiangen, Beijing, China) was used to remove DNA contamination, and to perform the reverse transcription. The real-time PCR assay was carried out on a CFX96TMreal-time PCR cycler (Bio-Rad, Hercules, CA, USA). The fluorescence real-time quantitative dye used the SYBR Premix Ex TaqTM II (Tli RNaseH Plus) Kit (Takara, Kusatsu, Japan). The gene amplification primers specific to the desired reaction design were taken from Primer Premier 5.0.0 (Premier Biosoft, Palo Alto, CA, USA). Nia2's primer sequences were F:5' - GTCGATGCGGGATATACAGT-3' and R:5'-CCATCGCCATCTCTTTCTTA- $3^{\prime}$. Pakchoi's actin was used as an internal reference. The actin's primer sequences were F: $5^{\prime}-$ AAACGCCTACCACATCCA- $3^{\prime}$ and R:5'-CCATCGCCATCTCTTTCTTA- $3^{\prime}$. The $2^{-\Delta \Delta C t}$ method was used to calculate the relative expression of the genes [22].

SPSS 22.0 software was used to analyze the experimental data, and Origin 2019 software was used to create the graphs. The statistical analysis for the data was performed through analysis of variance (ANOVA) by using Duncan's multiple range test $(p<0.05)$.

\section{Results}

\subsection{Under Different Nitrogen Levels, a Low R/FR Ratio Promoted the Growth of Pakchoi}

From Table 1, under non-stress conditions, it can be seen that low R/FR can significantly enhance the fresh weight, root length, leaf width and leaf length of pakchoi compared with the treatment $\mathrm{N}$ (the control). When $80 \mathrm{mmol} \cdot \mathrm{L}^{-1} \mathrm{NO}_{3}{ }^{-}$was added, the fresh weight, root length, leaf width and leaf length of the whole plant decreased by $42.1 \%, 22.2 \%, 23.4 \%$ and $4.2 \%$ after 15 days of treatment, respectively, in comparison with the control. The treatments with a low R/FR ratio (L80) provided better growth performance; the results showed that the fresh weight, root length, leaf width, and leaf length of the pakchoi were significantly greater than $\mathrm{N} 80$. With the addition of $160 \mathrm{mmol} \cdot \mathrm{L}^{-1} \mathrm{NO}_{3}{ }^{-}$, the growth of the pakchoi was severely inhibited, while the growth index of plants treated with low 
R/FR (L160) was significantly higher than that of N160. This showed that the reduction of the $\mathrm{R} / \mathrm{FR}$ ratio can lead to a high accumulation of the fresh weight, root length, leaf width, and leaf length of pakchoi, and has a positive effect on their growth.

Table 1. Effects of the changes of the R/FR ratio on the fresh weight, root length, leaf width and leaf length of pakchoi under different nitrogen levels. $\mathrm{N}$ : normal nutrient supply condition, $\mathrm{R} / \mathrm{FR}=4.2$; $\mathrm{L}$ : normal nutrient supply condition, $\mathrm{R} / \mathrm{FR}=0.7 ; \mathrm{N} 80$ : with the addition of $80 \mathrm{mmol} \cdot \mathrm{L}^{-1} \mathrm{NO}_{3}{ }^{-}$, $\mathrm{R} / \mathrm{FR}=4.2$; $\mathrm{L} 80$ : with the addition of $80 \mathrm{mmol} \cdot \mathrm{L}^{-1} \mathrm{NO}_{3}{ }^{-}, \mathrm{R} / \mathrm{FR}=0.7 ; \mathrm{N} 160$ : with the addition of $160 \mathrm{mmol} \cdot \mathrm{L}^{-1} \mathrm{NO}_{3}{ }^{-}, \mathrm{R} / \mathrm{FR}=4.2$; L160: with the addition of $160 \mathrm{mmol} \cdot \mathrm{L}^{-1} \mathrm{NO}_{3}{ }^{-}, \mathrm{R} / \mathrm{FR}=0.7$.

\begin{tabular}{ccccc}
\hline Treatments & $\begin{array}{c}\text { Fresh Weight } \\
\mathbf{( g )}\end{array}$ & $\begin{array}{c}\text { Root Length } \\
\mathbf{( \mathbf { c m } )}\end{array}$ & $\begin{array}{c}\text { Leaf Width } \\
\mathbf{( c m})\end{array}$ & $\begin{array}{c}\text { Leaf Length } \\
\mathbf{( c m )}\end{array}$ \\
\hline $\mathrm{N}$ & $122.60^{\alpha} \pm 0.88 \mathrm{~b} \beta$ & $39.00 \pm 1.00 \mathrm{~b}$ & $14.10 \pm 0.78 \mathrm{~b}$ & $19.20 \pm 0.46 \mathrm{~b}$ \\
$\mathrm{~L}$ & $215.60 \pm 0.26 \mathrm{a}$ & $45.50 \pm 1.63 \mathrm{a}$ & $17.20 \pm 0.46 \mathrm{a}$ & $22.00 \pm 0.61 \mathrm{a}$ \\
$\mathrm{N} 80$ & $71.00 \pm 2.65 \mathrm{~d}$ & $30.33 \pm 5.41 \mathrm{c}$ & $10.80 \pm 1.31 \mathrm{c}$ & $18.40 \pm 1.45 \mathrm{~b}$ \\
$\mathrm{~L} 80$ & $84.47 \pm 0.40 \mathrm{c}$ & $37.50 \pm 5.72 \mathrm{~b}$ & $14.50 \pm 0.17 \mathrm{~b}$ & $20.80 \pm 0.36 \mathrm{a}$ \\
$\mathrm{N} 160$ & $15.36 \pm 0.49 \mathrm{f}$ & $15.86 \pm 1.05 \mathrm{e}$ & $8.40 \pm 0.62 \mathrm{~d}$ & $8.30 \pm 0.78 \mathrm{~d}$ \\
L160 & $21.07 \pm 0.60 \mathrm{e}$ & $19.93 \pm 0.96 \mathrm{~d}$ & $9.76 \pm 0.75 \mathrm{~cd}$ & $12.16 \pm 0.80 \mathrm{c}$ \\
\hline
\end{tabular}

$\alpha$ Values shown are means \pm standard deviation $(n=3) .{ }^{\beta}$ Values followed by different letter(s) within a column for each species are significantly different $(p<0.05)$.

\subsection{The R/FR Ratio Affects the Content of Osmotic Regulatory Substances in Pakchoi under Different Nitrogen Levels}

It can be seen from Figure 1 that without the addition of nitrogen, the soluble sugar content of pakchoi showed an upward trend (0-10 d). After 10 days of treatment with low $\mathrm{R} / \mathrm{FR}$ conditions, there was no significance in the soluble sugar content of the $\mathrm{L}$ treatment or the $\mathrm{N}$ treatment. After the addition of $80 \mathrm{mmol} \cdot \mathrm{L}^{-1} \mathrm{NO}_{3}{ }^{-}$, the soluble sugar content of the N80 treatment increased 1.07 times compared with the $\mathrm{N}$ treatment on the tenth day. After the addition of far-red light, the soluble sugar content of the L80 treatment was increased. However, after the addition of $160 \mathrm{mmol} \cdot \mathrm{L}^{-1} \mathrm{NO}_{3}{ }^{-}$, the soluble sugar content of $\mathrm{N} 160$ was slightly higher than that of $\mathrm{N}$ on the tenth day, and the difference was not significant. After the addition of far-red light, the L160 treatment increased by $27 \%$ compared with the N160 treatment on day 10 of the treatment. The soluble protein content was consistent with the soluble sugar content trend. The soluble protein content of the pakchoi increased continuously within 10 days. After the addition of $80 \mathrm{mmol} \cdot \mathrm{L}^{-1} \mathrm{NO}_{3}{ }^{-}$, the $\mathrm{N} 80$ treatment increased significantly on the tenth day compared with the $\mathrm{N}$ treatment. After the addition of $160 \mathrm{mmol} \cdot \mathrm{L}^{-1} \mathrm{NO}_{3}{ }^{-}$, the soluble protein content of the $\mathrm{N} 160$ treatment decreased, but a low $\mathrm{R} / \mathrm{FR}$ ratio can increase the content of osmotic regulatory substances, reduce the harm of nitrogen stress, and promote the growth of pakchoi.

\subsection{Nitrate Content in Pakchoi under Different Nitrogen Levels of the R/FR Ratio}

It is shown in Figure 2 that the nitrate contents in the pakchoi leaves in N80 and N160 were 1.34 times and 1.81 times that in the control $(\mathrm{N})$ on day 10 of treatment, respectively. Consequently, the pakchoi leaves exposed to calcium nitrate stress contained a higher level of nitrate, which reduced their quality. However, as a result of the low R/FR treatment, the nitrate content of the $\mathrm{L}$ treatment was reduced by $14.0 \%$ compared to the $\mathrm{N}$ treatment, the L80 treatment was reduced by $22.7 \%$ compared with the N80 treatment, and the L160 treatment was reduced by $16.3 \%$ compared with the N160 treatment after 10 days of exposure to stress from an excess of $\mathrm{NO}_{3}{ }^{-}$. The above shows that the reduction of the $\mathrm{R} / \mathrm{FR}$ ratio can effectively reduce the nitrate content in the leaves of pakchoi. 

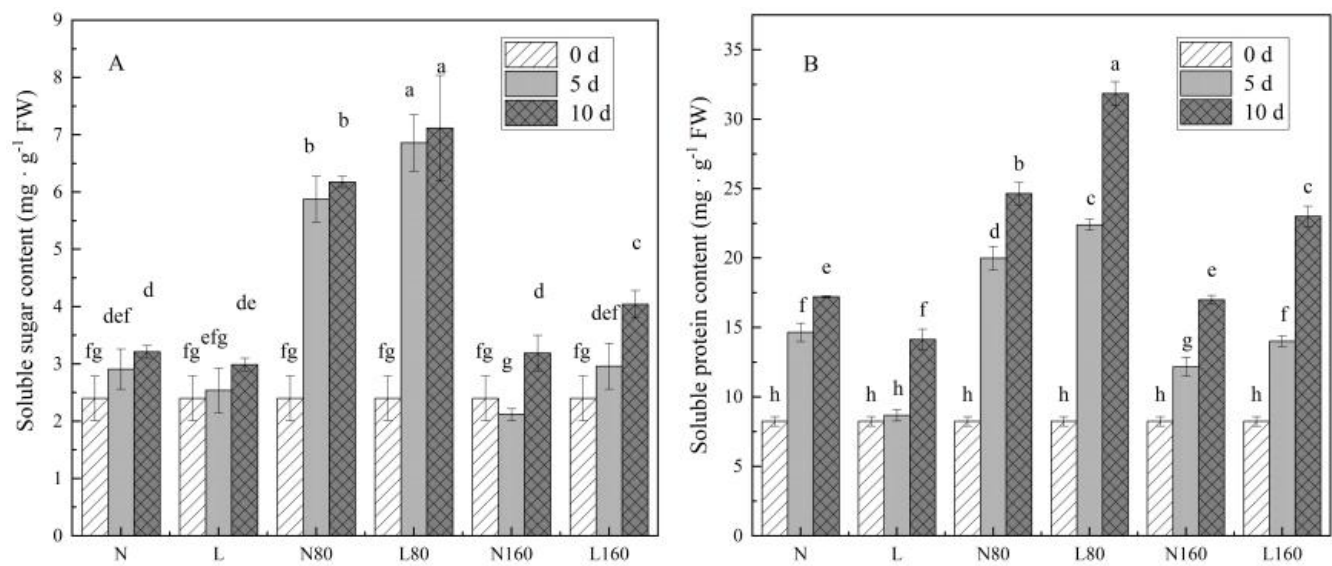

Figure 1. Effects of the changes of the R/FR ratio on the soluble sugar content (A) and soluble protein content (B) of pakchoi under different nitrogen levels. The values shown are means \pm standard deviation $(\mathrm{n}=3)$. Different letters $(\mathrm{a}-\mathrm{h})$ indicate significant differences at $p<0.05$ according to Duncan's multiple range test. $0 \mathrm{~d}$ : on day 0 after treatment; $5 \mathrm{~d}$ : on the fifth day after treatment; $10 \mathrm{~d}$ : on the tenth after treatment. $\mathrm{N}$ : normal nutrient supply condition, $\mathrm{R} / \mathrm{FR}=4.2$; $\mathrm{L}$ : normal nutrient supply condition, $\mathrm{R} / \mathrm{FR}=0.7$; $\mathrm{N} 80$ : with the addition of $80 \mathrm{mmol} \cdot \mathrm{L}^{-1} \mathrm{NO}_{3}{ }^{-}, \mathrm{R} / \mathrm{FR}=4.2$; L80: with the addition of $80 \mathrm{mmol} \cdot \mathrm{L}^{-1} \mathrm{NO}_{3}{ }^{-}, \mathrm{R} / \mathrm{FR}=0.7 ; \mathrm{N} 160$ : with the addition of $160 \mathrm{mmol}$. $\mathrm{L}^{-1} \mathrm{NO}_{3}{ }^{-}, \mathrm{R} / \mathrm{FR}=4.2 ; \mathrm{L} 160$ : added $160 \mathrm{mmol} \cdot \mathrm{L}^{-1} \mathrm{NO}_{3}{ }^{-}, \mathrm{R} / \mathrm{FR}=0.7$.

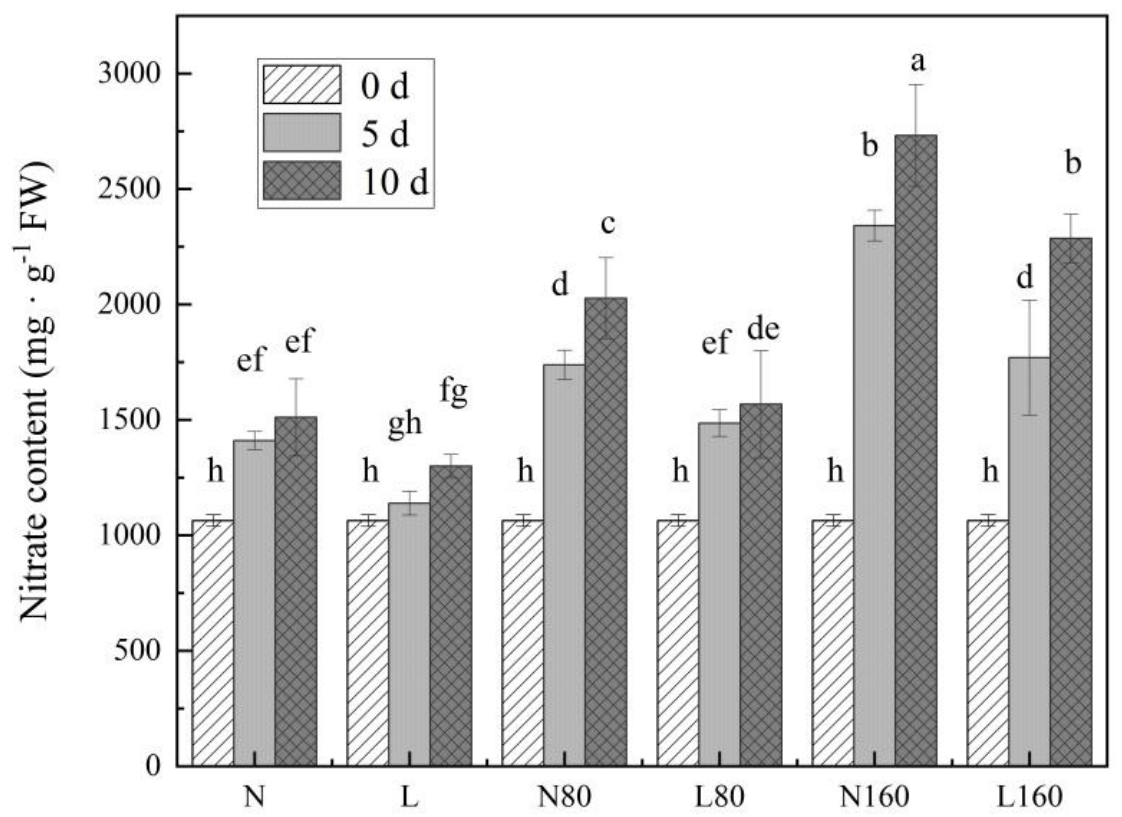

Figure 2. Effects of the changes of the R/FR ratio on the nitrate content of pakchoi under different nitrogen levels. Values shown are means \pm standard deviation $(\mathrm{n}=3)$. Different letters $(\mathrm{a}-\mathrm{h})$ indicate significant differences at $p<0.05$ according to Duncan's multiple range test. $0 \mathrm{~d}$ : on day 0 after treatment; $5 \mathrm{~d}$ : on the fifth day after treatment; $10 \mathrm{~d}$ : on the tenth after treatment. $\mathrm{N}$ : normal nutrient supply condition, $\mathrm{R} / \mathrm{FR}=4.2$; L: normal nutrient supply condition, $\mathrm{R} / \mathrm{FR}=0.7 ; \mathrm{N} 80$ : with the addition of $80 \mathrm{mmol} \cdot \mathrm{L}^{-1} \mathrm{NO}_{3}{ }^{-}$, $\mathrm{R} / \mathrm{FR}=4.2$; L80: with the addition of $80 \mathrm{mmol} \cdot \mathrm{L}^{-1} \mathrm{NO}_{3}{ }^{-}, \mathrm{R} / \mathrm{FR}=0.7$; $\mathrm{N} 160$ : with the addition of $160 \mathrm{mmol} \cdot \mathrm{L}^{-1} \mathrm{NO}_{3}{ }^{-}, \mathrm{R} / \mathrm{FR}=4.2 ; \mathrm{L} 160$ : added $160 \mathrm{mmol} \cdot \mathrm{L}^{-1} \mathrm{NO}_{3}{ }^{-}$, $\mathrm{R} / \mathrm{FR}=0.7$

\subsection{R/FR Ratio Affects the Activity of Nitrate Reductase in Pakchoi at Different Levels of Nitrogen}

As shown in Figure 3, without the addition of nitrogen, the nitrate reductase activity of pakchoi showed an upward trend within 10 days. On day 10 of treatment, with the addition of $80 \mathrm{mmol} \cdot \mathrm{L}^{-1} \mathrm{~N}(\mathrm{~N} 80)$, the activity of nitrate reductase in the leaves of pakchoi 
was significantly increased, and was $49.0 \%$ higher than that of the $\mathrm{N}$ treatment. After the addition of $160 \mathrm{mmol} \cdot \mathrm{L}^{-1} \mathrm{~N}(\mathrm{~N} 160)$, the nitrate reductase activity in pakchoi leaves dramatically decreased, declining by $59.0 \%$ from that in the $\mathrm{N}$ treatment. This indicated that a lower level $\left(80 \mathrm{mmol} \cdot \mathrm{L}^{-1}\right)$ of nitrogen increased the activity of nitrate reductase in the leaves of pakchoi, but a higher level $\left(160 \mathrm{mmol} \cdot \mathrm{L}^{-1}\right)$ of nitrogen weakened its activity. When treated with $\mathrm{R} / \mathrm{FR}=0.7$, the activity of nitrate reductase significantly increased. The $\mathrm{L}$ treatment increased the nitrate reductase activity by $51.8 \%$ compared with the $\mathrm{N}$ treatment after 10 days of exposure to stress from an excess of $\mathrm{NO}_{3}{ }^{-}$. In addition, the $\mathrm{L} 80$ treatment increased by $29.9 \%$ compared with the N80 treatment, and the L160 treatment increased by $242.7 \%$ compared with the N160 treatment at 10d. This indicates that the low $\mathrm{R} / \mathrm{FR}$ treatment would increase the nitrate reductase activity in pakchoi.

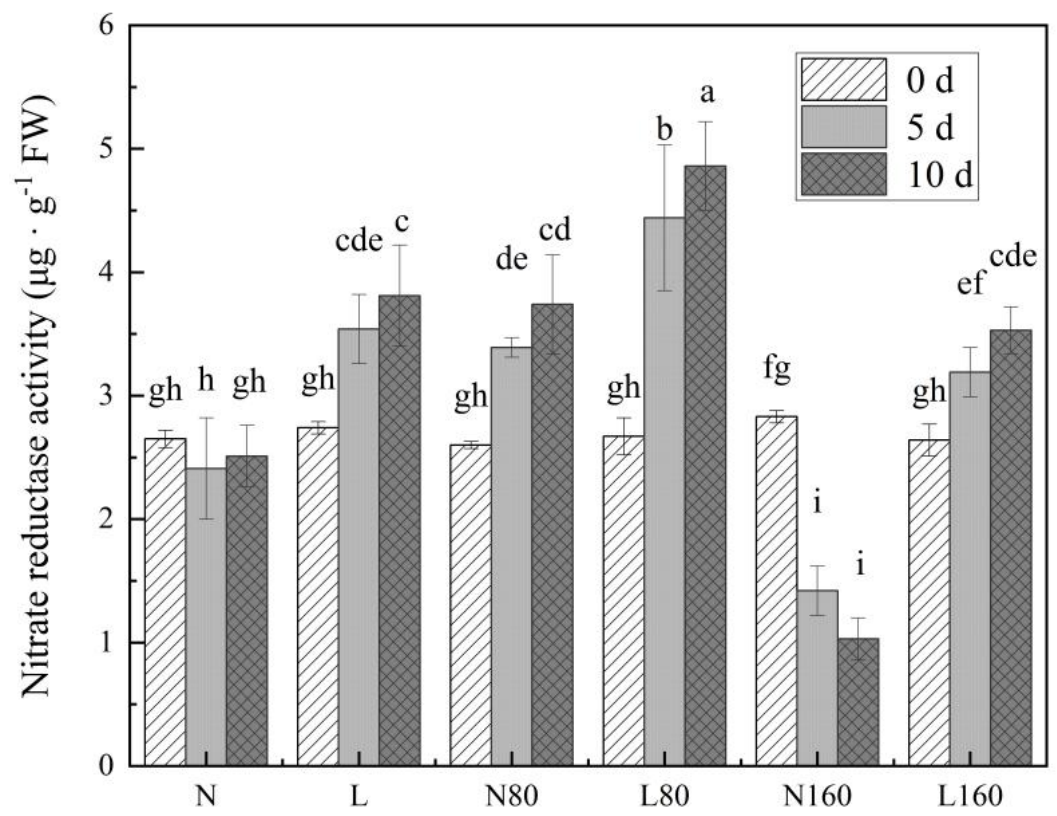

Figure 3. Effects of the changes of R/FR ratio on the nitrate reductase activity of pakchoi under different nitrogen levels. The values shown are means \pm standard deviation $(n=3)$. Different letters (a-i) indicate significant differences at $p<0.05$ according to Duncan's multiple range test. $0 \mathrm{~d}$ : on day 0 after treatment; $5 \mathrm{~d}$ : on the fifth day after treatment; $10 \mathrm{~d}$ : on the tenth after treatment. $\mathrm{N}$ : normal nutrient supply condition, $\mathrm{R} / \mathrm{FR}=4.2$; L: normal nutrient supply condition, $\mathrm{R} / \mathrm{FR}=0.7$; N80: with the addition of $80 \mathrm{mmol} \cdot \mathrm{L}^{-1} \mathrm{NO}_{3}{ }^{-}, \mathrm{R} / \mathrm{FR}=4.2 ; \mathrm{L} 80$ : with the addition of $80 \mathrm{mmol} \cdot \mathrm{L}^{-1} \mathrm{NO}_{3}{ }^{-}$, $\mathrm{R} / \mathrm{FR}=0.7$; $\mathrm{N} 160$ : with the addition of $160 \mathrm{mmol} \cdot \mathrm{L}^{-1} \mathrm{NO}_{3}{ }^{-}, \mathrm{R} / \mathrm{FR}=4.2$; L160: with the addition of $160 \mathrm{mmol} \cdot \mathrm{L}^{-1} \mathrm{NO}_{3}{ }^{-}, \mathrm{R} / \mathrm{FR}=0.7$.

\subsection{Levels of R/FR Have Different Effects on Nia2 Gene Expression under Different Nitrogen Levels in Pakchoi}

According to the results (Figure 4), the expression of the Nia2 gene increased initially within $72 \mathrm{~h}$ and then declined under non-stress conditions. The peak occurs at $12 \mathrm{~h}$. On the other hand, the expression of the Nia 2 gene under $\mathrm{R} / \mathrm{FR}=0.7$ is always higher than that with white light treatment. Under nitrogen stress, N80 treatment first inhibited pakchoi Nia2 gene expression, and then promoted it over time. By contrast, the L80 treatment increased the expression of the Nia2 gene. At $72 \mathrm{~h}$, the expression of the Nia2 gene was 9.5 times that at $0 \mathrm{~h}$, and was significantly higher than that under N80 treatment. Under $160 \mathrm{mmol} \cdot \mathrm{L}^{-1}$ conditions, the Nia2 gene expression in pakchoi showed a trend of first increasing and then decreasing, reaching a peak at $24 \mathrm{~h}$. Moreover, the expression of the Nia2 gene under light quality treatment with $\mathrm{R} / \mathrm{FR}=0.7$ is better than that under whitelight treatment. There were also significances at the different time points ( $3 \mathrm{~h}-72 \mathrm{~h}$ ) in N and $\mathrm{L}$, respectively (Table S1). 


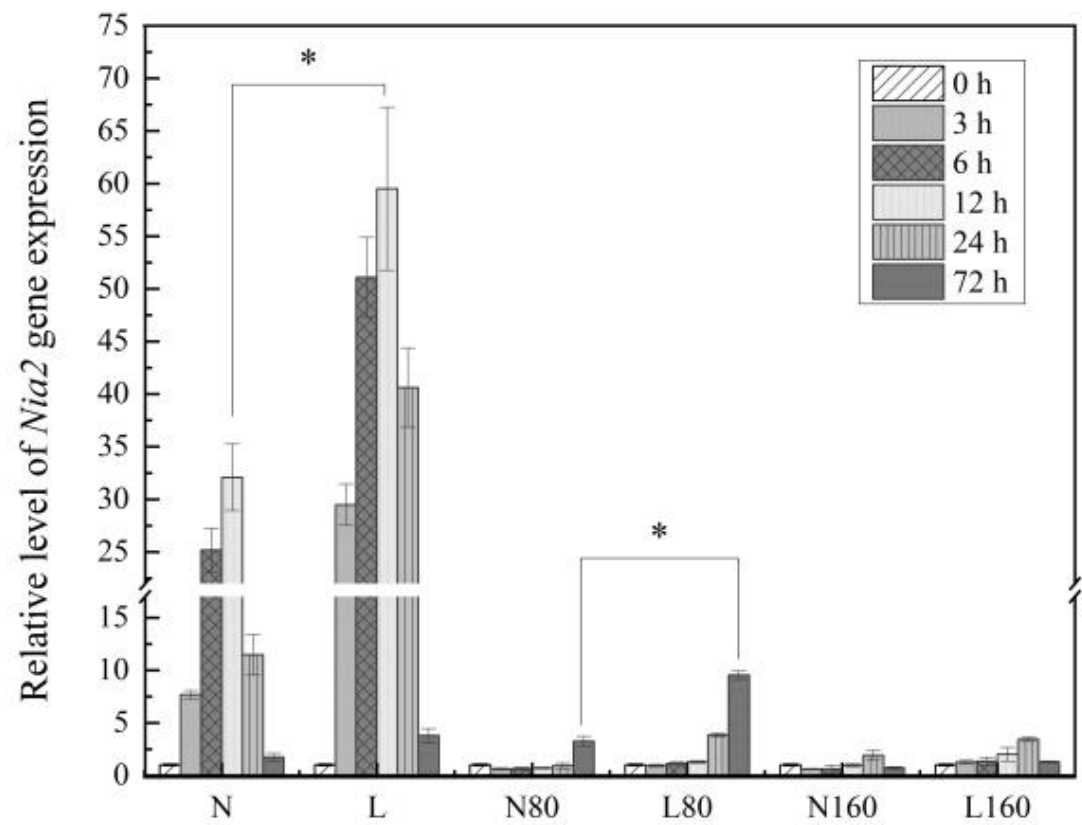

Figure 4. Expression levels of the Nia2 gene in leaves of pakchoi under different R/FR ratio and $\mathrm{N}$ levels at $0,3,6,12,24,72 \mathrm{~h}$. The relative gene expression levels were detected by quantitative reverse transcription polymerase chain reaction (RT-qPCR) using actin as the reference gene. ${ }^{*} p<0.05$. $0 \mathrm{~h}: 0 \mathrm{~h}$ after treatment; $3 \mathrm{~h}$ : at the $3 \mathrm{rd}$ hour after treatment; $6 \mathrm{~h}$ : at the 6 th hour after treatment; $12 \mathrm{~h}$ : at the 12th hour after treatment; $24 \mathrm{~h}$ : at the 24th hour after treatment; $72 \mathrm{~h}$ : at the $72 \mathrm{nd}$ hour after treatment. N: normal nutrient supply condition, $\mathrm{R} / \mathrm{FR}=4.2 ; \mathrm{L}$ : normal nutrient supply condition, $\mathrm{R} / \mathrm{FR}=0.7$; $\mathrm{N} 80$ : with the addition of $80 \mathrm{mmol} \cdot \mathrm{L}^{-1} \mathrm{NO}_{3}{ }^{-}, \mathrm{R} / \mathrm{FR}=4.2$; L80: with the addition of $80 \mathrm{mmol} \cdot \mathrm{L}^{-1} \mathrm{NO}_{3}{ }^{-}$, R/FR $=0.7$; N160: with the addition of $160 \mathrm{mmol} \cdot \mathrm{L}^{-1} \mathrm{NO}_{3}{ }^{-}, \mathrm{R} / \mathrm{FR}=4.2$; L160: with the addition of $160 \mathrm{mmol} \cdot \mathrm{L}^{-1} \mathrm{NO}_{3}{ }^{-}, \mathrm{R} / \mathrm{FR}=0.7$.

\section{Discussion}

Red light can reduce the length of internodes and plant height, while far-red light can increase the length of internodes and plant height [23]. The reduction of the R/FR ratio can promote plant stem growth and adjust the phytochrome to adapt to the external environment [24,25]. In this study, we showed that low R/FR could significantly enhance the fresh weight, root length, leaf width and leaf length of pakchoi under non-stress conditions. Similarly, Yang et al. [26] revealed that the reductions in the R/FR ratio increased the height and stem mass fractions of soybean seedlings. Yang et al. [7] also found that a low R/FR ratio significantly increased the total biomass and leaf area of soybean seedlings.

When plants are under salt stress, their normal life activities are blocked, and the growth of plant organs and tissues are inhibited [27]. Recent studies have shown that a low $\mathrm{R} / \mathrm{FR}$ value can significantly reduce the oxidative damage induced by salt stress, and can reduce the inhibition of PSII electron transfer and promote seedling growth [11]. In this study, we found that the growth of pakchoi was inhibited under high nitrogen stress, with a decrease in the fresh weight, leaf width, and leaf length (Table 1). Similar observations were found in tomato seedlings under high nitrogen stress by Zhou et al. [28]. However, a higher proportion of far-red light in the environment can significantly improve the accumulation of the fresh weight of pakchoi under high nitrogen concentrations (Table 1). This is consistent with the literature reported by Zhu et al. [29] and Cao et al. [11]. In addition, the reduction of the R/FR ratio accelerated the photosynthesis capacity in pakchoi under excess nitrate stress [30]. Another study found that a low R/FR ratio promoted the net photosynthetic rate by increasing the expression of a Rubisco gene (RBCS) of tomato seedlings under calcium nitrate stress [28]. Thus, the enhancement of a low R/FR ratio on photosynthesis may provide the plants with the potential for growth under excess nitrate stress. 
Soluble protein and soluble sugar are important osmotic adjustment substances in plants; they can alleviate the water stress caused by salt damage and other adversities, maintain a certain turgor pressure in cells, and ensure the normal operation of plant metabolic activities [31]. In this study, the addition of $80 \mathrm{mmol} \cdot \mathrm{L}^{-1} \mathrm{NO}_{3}{ }^{-}$significantly promoted the nitrogen metabolism of pakchoi, causing the soluble protein content and soluble sugar content to increase significantly. However, it showed a downward trend under a higher nitrogen treatment (N160). The study of Sun et al. [32] also showed that high nitrogen application was not conducive to sugar accumulation in the later period of beet root tubers. The reduction of the $\mathrm{R} / \mathrm{FR}$ ratio can increase the osmotic adjustment substances of pakchoi, indicating that a low $\mathrm{R} / \mathrm{FR}$ ratio can alleviate excessive $\mathrm{NO}_{3}{ }^{-}$stress.

$\mathrm{NR}$ is the key enzyme in regulation of the nitrate content in higher plants $[17,18]$. In this study, a low R/FR ratio enhanced the activities of $\mathrm{NR}$ under both excessive $\mathrm{NO}_{3}{ }^{-}$ stress and non-stress. Under the excessive $\mathrm{NO}_{3}{ }^{-}$stress, the content of nitrate was increased, while it was inhibited by the low $\mathrm{R} / \mathrm{FR}$ ratio. These results indicated that a low $\mathrm{R} / \mathrm{FR}$ ratio can reduce nitrate accumulation under excessive $\mathrm{NO}_{3}{ }^{-}$stress by regulating the NR activity of pakchoi. The Nia gene encodes the NR protein, which plays an important role in nitrogen metabolism. Previous studies have reported that the transcriptional abundance of Nia mRNA was related to the nitrogen source, concentration and induction time of the induction substrate [33]. In our study, there was a significant decrease $3 \mathrm{~h}$ after high nitrate stress $\left(80 \mathrm{mmol} \cdot \mathrm{L}^{-1}\right.$ and $\left.160 \mathrm{mmol} \cdot \mathrm{L}^{-1}\right)$. This indicated that the Nia gene can quickly respond to the change of the nitrogen level. Mesnard and Ratcliffe [34] thought that there is a self-regulation mechanism in the plant nitrogen metabolism system. They pointed out that the assimilation amount of $\mathrm{NO}_{3}{ }^{-}$of plants balances with their metabolism, i.e., the amino acids produced per unit of time should not exceed the metabolic requirements. Otherwise, the accumulation of $\mathrm{NO}_{2}{ }^{-}$will cause toxic effects to the cells. Thus, the reduction of $\mathrm{Nia}$ gene expression could be an adaptation mechanism under high nitrate stress. In this study, with the low R/FR ratio treatment, the Nia2 gene expression in L80 was always higher than that of N80. Similar results were also found in the concentration of $160 \mathrm{mM}$ of nitrate stress. This might be attributed to the interaction of nitrogen and light. Studies have shown that the reduction of the red light to blue light ratio promotes the nitrogen metabolism [35-37], but there are few reports related to the effect of a low R/FR ratio on nitrogen metabolism, especially regarding Nia gene expression [38]. According to the study reported by Jonassen et al. [39], HY5 (ELONGATED HYPOCOTYL5) positively regulates nitrate reductase in plants. The author also found direct evidence of the positive regulation of Nia by HY5 in Arabidopsis thaliana. In addition, HY5 can sense and transmit light signals, including the change of the $\mathrm{R} / \mathrm{FR}$ ratio [40]. The question of whether reducing the $\mathrm{R} / \mathrm{FR}$ ratio enhances Nia2 gene expression via HY5 needs further research.

\section{Conclusions}

In conclusion, the growth of pakchoi was inhibited under high nitrogen levels, but the reduction of the ratio of red light to far-red light in the environment can significantly improve its soluble protein content, soluble sugar content and nitrate reductase activity, and can regulate the expression of the nitrate reductase gene of pakchoi positively, so as to reduce the nitrate content and alleviate the negative effects of a high nitrogen level in pakchoi.

Supplementary Materials: The following supporting information can be downloaded at: https:// www.mdpi.com/article/10.3390/horticulturae8030186/s1, Table S1: Expression levels of Nia2 gene in leaves of pakchoi under different LED light quality and $\mathrm{N}$ levels at 0, 3, 6, 12, 24, $72 \mathrm{~h}$.

Author Contributions: Conceptualization, X.Z.; Data curation, L.C.; Investigation, Q.L. and Y.T.; Methodology, L.C., Q.L., Z.L., X.C., J.H. (Jiaxi Han), Y.G. and Y.H.; Project administration, L.C. and X.Z.; Software, Q.L.; Supervision, X.Z.; Validation, C.J.; Writing—original draft, J.H. (Jia Huang); Writing-review and editing, J.H. (Jia Huang). J.H. (Jia Huang) and L.C. contributed equally to this paper. All authors have read and agreed to the published version of the manuscript. 
Funding: This research was funded by College Students'innovative Entrepreneurial Training Plan Program [040/2021998128]. And The APC was funded by Specialized Subject Construction Support Plan Level Funding [040/2121997831].

Institutional Review Board Statement: Not applicable.

Informed Consent Statement: Not applicable.

Data Availability Statement: Not applicable.

Acknowledgments: This work was supported by College Students' Innovative Entrepreneurial Training Plan Program [040/2021998128].

Conflicts of Interest: The authors declare no conflict of interest.

\section{References}

1. Yuan, L.Y.; Shu, S.; Sun, J.; Guo, S.R.; Tezuka, T. Effects of 24-epibrassinolide on the photosynthetic characteristics, antioxidant system, and chloroplast ultrastructure in Cucumis sativus L. under $\mathrm{Ca}\left(\mathrm{NO}_{3}\right)_{2}$ stress. Photosynth. Res. 2012, 112, 205-214. [CrossRef] [PubMed]

2. Sun, Z.D.; Han, X.R.; Peng, J.; Fan, F.; Zhang, Q.G. Effect of Exogenous Nitric Oxide on PSII Function and Distribution and Utilization of Luminous Energy in Tomato Seedlings Under Stress of Ca(NO$\left.)_{2}\right)_{2}$. J. Nucl. Agric. Sci. 2016, 30, $2451-2459$.

3. Sheng, H.J.; Du, Y.; Shen, R.; Shan, Y.H. Effect of soluble salt content in secondary salinized soil from protected culture on seedling emergence and growth of pakchoi. J. Yangzhou Univ. 2015, 36, 100-104.

4. Gu, D.Y.; Wang, X.F.; Gao, J.J.; Jiao, J.; Liu, Z.L.; Zhang, Y.Y. Effects of purified humic acid on the growth and nitrogen metabolism of cucumber seedlings under nitrogen stress. Chin. J. Appl. Ecol. 2018, 29, 2575-2582.

5. Park, Y.; Runkle, E.S. Far-red radiation promotes growth of seedlings by increasing leaf expansion and whole-plant net assimilation. Environ. Exp. Bot. 2017, 136, 41-49. [CrossRef]

6. Zhen, S.Y.; van Iersel, M.W. Far-red light is needed for efficient photochemistry and photosynthesis. J. Plant Physiol. 2017, 209, 115-122. [CrossRef]

7. Yang, F.; Liu, Q.L.; Cheng, Y.J.; Feng, L.Y.; Wu, X.L.; Fan, Y.F.; Raza, M.A.; Wang, X.C.; Yong, T.W.; Liu, W.G.; et al. Low red/far-red ratio as a signal promotes carbon assimilation of soybean seedlings by increasing the photosynthetic capacity. BMC Plant Biol. 2020, 20, 148. [CrossRef]

8. $\quad$ Cheng, Y.J.; Chen, J.X.; Wang, Z.L.; Fan, Y.F.; Chen, S.Y.; Li, Z.L.; Liu, Q.L.; Li, Z.C.; Yang, F.; Yang, W.Y. Effects of Light Intensity and Light Quality on Morphological and Photosynthetic Characteristics of Soybean Seedlings. Sci. Agric. Sin. 2018, 51, 2655-2663.

9. Wang, F.; Wu, N.; Zhang, L.Y.; Ahammed, G.J.; Chen, X.X.; Xiang, X.; Zhou, J.; Xia, X.J.; Shi, K.; Yu, J.Q.; et al. Light SignalingDependent Regulation of Photoinhibition and Photoprotection in Tomato. Plant Physiol. 2018, 176, 1311-1326. [CrossRef]

10. Boggs, J.Z.; Loewy, K.; Bibee, K.; Heschel, M.S. Phytochromes influence stomatal conductance plasticity in Arabidopsis thaliana. Plant Growth Regul. 2010, 60, 77-81. [CrossRef]

11. Cao, K.; Yu, J.; Xu, D.W.; Ai, K.Q.; Bao, E.C.; Zou, Z.R. Exposure to lower red to far-red light ratios improve tomato tolerance to salt stress. BMC Plant Biol. 2018, 18, 92. [CrossRef] [PubMed]

12. Franklin, K.A.; Quail, P.H. Phytochrome functions in Arabidopsis development. J. Exp. Bot. 2020, 61, 11-24. [CrossRef] [PubMed]

13. Fahad, S.; Hussain, S.; Matloob, A.; Khan, F.A.; Khaliq, A.; Saud, S.; Hassan, S.; Shan, D.; Khan, F.; Ullah, N.; et al. Phytohormones and plant responses to salinity stress: A review. Plant Growth Regul. 2015, 75, 391-404. [CrossRef]

14. Liu, C.Y.; Li, Z.X.; Yu, D. Analysis and Determination on Nutrients of Chinese Cabbage. Chin. Hortic. Abstr. 2014, 30, 29-31. [CrossRef]

15. Wang, J.; Ma, Q.X.; Liu, M.J.; Zhou, J.J.; Hu, Z.P.; Wu, L.H. Effects of different amino acids and different ratios of lysine and nitrate on the growth and quality of Chinese cabbage (Brassica pekinensis L.). Plant Nutr. Fertil. Sci. 2020, 26, 587-593.

16. Zhang, J.L. Effects of different nitrogen fertilizer varieties on the yield and nitrate content of cabbage. Food Nutr. China 2006, 5, 25-26.

17. Zhang, X.Q.; Guo, P.F.; Zhang, K.; Wan, W.L.; Diao, M. Effects of drip irrigation frequency and nitrogen application on tomato growth and nitrate reductase. J. Shihezi Univ. 2018, 36, 57-62.

18. Yu, T.F.; Liu, X.J.; Zhang, X.L.; Hao, F. Effects of nitrogen on nitrogen content and nitrate reductase activity in root stem and leaf of alfalfa. Grassl. Turf 2017, 37, 14-20.

19. Liang, L. Study of nitrate reductase activity on nitrate accumulation and related metabolic regulation in pakchoi. Master's Thesis, Nanjing Agricultural University, Nanjing, China, 2008.

20. Guo, J.L.; Zhang, J.X. Review and Outlook of the Research on Nitrate Content of Vegetables. North. Hortic. 2011, 11, 183-188.

21. Xiong, Q.E. A Experimental Course of Plant Physiology; Sichuan Science and Technology Press: Chengdu, China, 2003.

22. Livak, K.J.; Schmittgen, T.D. Analysis of relative gene expression data using real-time quantitative PCR. Methods 2002, 25, 402-408. [CrossRef] 
23. Hu, L.P.; Cao, K.; Zou, Z.R. Effects of different far-red light intensity and red light on tomato seedlings. In Proceedings of the 2013 Symposium on High Quality and Safe Production Technology of Vegetables and On-Site Observation Meeting of Facility Horticulture Branch of China Horticultural Society, Guangzhou, China, 21-24 November 2013.

24. Possart, A.; Xu, T.; Paik, I.; Hanke, S.; Keim, S.; Hermann, H.M.; Wolf, L.; Hiß, M.; Becker, C.; Huq, E.; et al. Characterization of phytochrome interacting factors from the moss physcomitrella patentsillustrates conservation of phytochrome signaling modules in land plants. Plant Cell 2017, 29, 310-330. [CrossRef] [PubMed]

25. Sheerin, D.J.; Menon, C.; zur Oven-Krockhaus, S.; Enderle, B.; Zhu, L.; Johnen, P.; Schleifenbaum, F.; Stierhof, Y.D.; Huq, E.; Hiltbrunner, A. Light-activated phytochrome A and B interact with members of the SPA family to promote photomorphogenesis in Arabidopsis by reorganizing the COP1/SPA complex. Plant Cell 2015, 27, 189-201. [CrossRef] [PubMed]

26. Yang, F.; Fan, Y.F.; Wu, X.L.; Cheng, Y.J.; Liu, Q.L.; Feng, L.Y.; Chen, J.X.; Wang, Z.L.; Wang, X.C.; Yong, T.W.; et al. Auxin-togibberellin ratio as a signal for light intensity and quality in regulating soybean growth and matter partitioning. Front. Plant Sci. 2018, 9, 56. [CrossRef] [PubMed]

27. Zhang, J.L.; Li, H.R.; Guo, S.Y.; Wang, S.M.; Shi, H.Z.; Han, Q.Q.; Bao, A.K.; Qing, M.A. Research advances in higher plant adaptation to salt stress. Acta Prataculturae Sin. 2015, 24, 220-236.

28. Zhou, X.T.; Li, Z.L.; He, J.J.; Wang, X.Y.; Liu, Q.L.; Huang, J.; Xie, Y.D.; He, Z.Q. Effects of red to far-red light ratio on growth and photosynthetic characteristics of tomato seedlings under calcium nitrate stress. Photosynthetica 2021, 59, 625-632. [CrossRef]

29. Zhu, M.; Li, X.Y.; Zhang, T.T.; Chen, L. Effects of far red light irradiation on the germination and seedling growth of rice under salt and drought stress. J. China Agric. Univ. 2021, 26, 21-32.

30. Li, Z.L.; Chen, G.Y.; Gao, F.Q.; Luo, J.P.; Li, C.W.; He, Z.Q.; Zhou, X.T. Effects of different light quality ratio on growth and photosynthesis capacity in pakchoi under excess nitrate stress. IOP Conf. Ser. Earth Environ. Sci. 2021, 621, 012105. [CrossRef]

31. Liu, J.X.; Ou, X.B.; Wang, J.C. Effects of exogenous hydrogen peroxide on growth and resistance physiology of naked oat seedlings under saline-alkali mixed stress. Bull. Bot. Res. 2019, 39, 181-191.

32. Liu, N.; Song, B.Q.; Yan, Z.S.; Fan, Y.J.; Yang, J.S. Effect of nitrogen application on the content of soluble sugar and key enzyme activities in sugar metabolism of sugar beet. Chin. Agric. Sci. Bull. 2015, 31, 183-189.

33. Ding, G.Z.; Hou, J.; Chen, L.; Ma, F.M.; Chen, L.J. Cloning of Nia gene and its differential expression induced by different nitrogen forms in sugar beet (Beta vulgaris L.). Acta Agron. Sin. 2011, 37, 1949-1955. [CrossRef]

34. Mesnard, F.; Ratcliffe, R.G. Nmr analysis of plant nitrogen metabolism. Photosynth. Res. 2005, 83, 163-180. [CrossRef] [PubMed]

35. Sun, N.; Wei, M.; Li, Y.; Wang, X.F.; Yang, F.J.; Shi, Q.H. Effects of light quality on carbon and nitrogen metabolism and enzyme activities in tomato seedlings. Acta Hortic. Sin. 2016, 43, 80-88.

36. Tang, D.W.; Zhang, G.B.; Zhang, F.; Pan, X.M.; Yu, J.H. Effects of different LED light qualities on growth and physiological and biochemical characteristics of cucumber seedlings. J. Gansu Agric. Univ. 2011, 46, 44-48.

37. Qin, Y.M.; Han, F.Y.; Yang, H.; Liu, M. Effects of light quality on morphogenesis and carbon and nitrogen metabolism of bitter gourd seedlings. China Cucurbits Veg. 2020, 33, 24-27.

38. Wang, Z.R.; Wang, H.Y.; Deng, H.F.; Xu, C.Q. Regulation of transcription factor HY5 in plant photomorphogenesis and nitrogen metabolism. China Veg. 2018, 5, 20-27.

39. Jonassen, E.M.; Lea, U.S.; Lillo, C. Hy5 and hyh are positive regulators of nitrate reductase in seedlings and rosette stage plants. Planta Berl. 2008, 227, 559-564. [CrossRef] [PubMed]

40. Chen, X.B.; Yao, Q.F.; Gao, X.H.; Jiang, C.F.; Nicholas, P.H.; Fu, X.D. Shoot-to-root mobile transcription factor hy5 coordinates plant carbon and nitrogen acquisition. Curr. Biol. 2016, 26, 640-646. [CrossRef] 